\title{
Scheuer Fibrosis Score
}

National Cancer Institute

\section{Source}

National Cancer Institute. Scheuer Fibrosis Score. NCI Thesaurus. Code C119573.

A scoring system for liver fibrosis developed by Scheuer (Scheuer PJ. Classification of viral hepatitis: a need for reassessment. J Hepatol 1991;13:372-374), based on a 5 category scale. 